\title{
Evidence supporting the use of Combretum nigricans as an antimalarial agent in Ethnomedicine
}

\author{
Enegide Chinedu ${ }^{1,2}$, Akah Peter $A^{2}$, Ofili Charles $C^{3}$, Agatemor Uzuazokaro $M^{1}$, Ameh Solomon $F^{4}$, \\ Jacob Dabum $L^{5}$, Onah Ifeoma $A^{6}$ \\ ${ }^{1}$ Department of Pharmacology, Novena University, Ogume, Delta State, Nigeria \\ ${ }^{2}$ Department of Pharmacology \& Toxicology, Faculty of Pharmaceutical Sciences, University of Nigeria, \\ Nsukka, Nigeria \\ ${ }^{3}$ Department of Public and Community Health, Novena University, Ogume, Delta State, Nigeria \\ ${ }^{4}$ Department of Pharmacology \& Toxicology, National Institute for Pharmaceutical Research and \\ Development, Idu, Abuja, Nigeria \\ ${ }^{5}$ Department of Human Physiology, Faculty of Medical Sciences, University of Jos, Jos, Nigeria \\ ${ }^{6}$ Department of Pharmaceutical Microbiology \& Biotechnology, Faculty of Pharmaceutical Sciences, University of \\ Nigeria, Nsukka, Nigeria
}

\begin{abstract}
Background: Combretum nigricans (Combretaceae) is a small, smooth bark tree used in traditional medicine to treat prurigo, dysentery, fever, and other symptoms of acute malaria in North-Central Nigeria. Methods: The antimalarial activity of C. nigricans hydro-methanol crude leaf extract was evaluated against Plasmodium berghei in mice. The Peters' 4-day suppressive test against early malaria infection and Rane's curative test against established malaria were employed in assessing the antimalarial activity of the crude extract. In each test model, five groups containing five mice each were used. Group 1 mice were administered with $10 \mathrm{ml}$ distilled water/kg b.w. p.o., groups 2 - 4 were administered with 200, 400, and $800 \mathrm{mg}$ extract/kg b.w. p.o. respectively, while group 5 mice were administered with artesunate $10 \mathrm{mg} / \mathrm{kg}$ b.w. p.o. Result: All doses of C. nigricans extract employed for the study (200 - $800 \mathrm{mg} / \mathrm{kg} \mathrm{b.w.} \mathrm{p.o.)} \mathrm{gave}$ significant $(P<0.05)$ chemosuppressive effect against $P$. berghei, this effect was observed to be dose-related; while the $400 \mathrm{mg} / \mathrm{kg}$ extract dose gave the highest curative effect. Compared to control, the extract also prolonged the mean survival time at all doses and as well prevented the characteristic decrease in body temperature elicited by P. berghei in mice. The LD50 of the extract was $>5000 \mathrm{mg} / \mathrm{kg}$ b.w. p.o. in mice. Conclusion: The result from the study indicates that C. nigicans crude leaf extract is safe orally and possesses significant antimalarial activity.
\end{abstract}

KEYWORDS: Combretum nigricans; Antimalarial; In vivo; Plasmodium berghei

\section{INTRODUCTION}

$\mathrm{M}$ alaria remains a significant public health problem (especially in most developing countries), with about 250 million new cases and over 600,000 mortalities annually. [ 1 - 4] About $40 \%$ of the world's population is currently at risk of being infected with malaria. [5] Africa, however, accounts for most of the global malaria cases (about 88\%) and mortality (about 90\%). Most of the recorded severe cases and mortalities in the sub-Saharan African region occur in pregnant women and children less than 5 years of age.[6] Though several agents are currently available for treatment and prophylaxis against malaria, it is still one of the most significant global health threats, maintaining its ranking among the top five causes of mortality among children less than 5 years of age. This can be primarily attributed to the increasing malaria parasite resistance to currently available antimalarial agents,

Correspondence: Enegide Chinedu, Department of Pharmacology, Novena University,

Ogume, Delta State, Nigeria E-mail: chinex.snow@gmail.com

\begin{tabular}{|ll} 
&
\end{tabular}


including quinine, mefloquine, chloroquine, atovaquone, and sulfadoxine/pyrimethamine. [7 - 10] This challenge has necessitated the need to develop new antimalarial agents.

Medical chronicles have shown that plants are a vital source for developing new drugs, including antimalarials.[11, 12] As a matter of fact, some of the currently used antimalarial agents were derived from plant sources; these include the premiere antimalarial agent, quinine (derived from the stem-bark of cinchona plant), and the current standard antimalarial drug, artemisinin (derived from Artemisia annua). [13] These successes, coupled with the fact that several other plants are currently being used traditionally in various parts of the world to manage malaria, have actuated more research into medicinal plants to develop new antimalarial agents. About $80 \%$ of the African population still depends on herbs to manage several ailments, including malaria.[14, 15] Combretum nigricans is one such plant; it is a small tree with smooth bark found in NorthCentral Nigeria and is traditionally used to treat malaria fever. The seed has been reported to possess hypotensive and central nervous system depressant activities, [16] while the antileishmaniasis activity has also been reported. [17] The plant has also been reported to possess antifungal activity [16] as well as cytotoxic effect. [18] In this light, the aim of this study was to evaluate the antimalarial activity of $\mathrm{C}$. nigricans crude extract in mice and hence seek if there is a scientific justification for its traditional application for the management of malaria.

\section{Material and methodology}

Plant materials: Fresh leaves of Combretum nigricans were collected from Jos-North Local Government Area, Plateau State, Nigeria. It was identified and authenticated by Mr. Jeffrey Azila, a taxonomist at the Federal College of Forestry, Jos, Plateau State, Nigeria. In addition, a voucher specimen (FHJ223) was prepared and deposited at the Federal College of Forestry herbarium for future reference.

Extraction: The leaf samples were rinsed, airdried (for two weeks), and pulverized into a fine powder using a plant milling machine. Using standard procedure as illustrated by Handa et al.,[19], the pulverized leaves $(1.6 \mathrm{~kg})$ were macerated in methanol-water $(1: 1) \mathrm{v} / \mathrm{v}$ for 48 $h$ with intermittent vigorous shaking. After 48 $\mathrm{h}$, the mixture was filtered using muslin cloth followed by Whatman filter paper (No.1). The obtained crude extract was concentrated and stored at $4^{\circ} \mathrm{C}$ in a refrigerator till use.

Phytochemical analysis: The crude extract was subjected to phytochemical analysis for constituent identification using standard procedures illustrated by Harborne 20] and Evans [21] to test for the presence of alkaloids, saponin, glycosides, carbohydrates, flavonoids, tannins, terpenoids, resins, proteins, reducing sugar, quinines, and steroids.

Animals: Swiss albino mice of both sexes (weighing $22 \pm 1.08 \mathrm{~g}$ ) housed at the animal facility of the Department of Pharmacology and Toxicology, University of Nigeria, Nsukka, were used. The animals were housed in standard cages under standard laboratory conditions at room temperature, and humidity with a 12-h light/dark cycle and ad libitum access to mice feed and water. All animal experiments were conducted following the NIH guidelines for laboratory animal care and use (Revised 1985) [22] and the University of Nigeria regulations for laboratory animal use.

Acute toxicity test $\left(\mathbf{L D}_{\mathbf{5 0}}\right)$ : The $C$. nigricans crude extract's acute oral toxicity was carried out on Swiss albino mice using Lorke's method. [23] A total of 12 mice of either sex were fasted overnight before the study. The study involved two phases. In the first phase, nine mice were randomly divided into three groups of three mice each and were administered the extract doses of 10,100 , and $1000 \mathrm{mg} / \mathrm{kg}$ body weight orally, respectively. They were observed critically for the first $4 \mathrm{~h}$ after dosing and subsequently for $24 \mathrm{~h}$ for signs of toxicity and mortality. In the second phase, three fresh mice were divided into three groups, one per group, and were administered extract doses of 1600, 2900, and $5000 \mathrm{mg} / \mathrm{kg}$ body weight, respectively. The animals were observed for signs of toxicity and mortality for the first $4 \mathrm{~h}$ and subsequently for $24 \mathrm{~h}$. They were further observed for 2 weeks for delayed toxicity. The $\mathrm{LD}_{50}$ (acute toxicity dose) was calculated using the following formula:

$\mathrm{LD}_{50}=\sqrt{ }$ (highest non-lethal dose $\times$ least lethal dose)

Rodent parasite [Plasmodium berghei (NK65)]: The rodent parasite was sourced from the Faculty of Veterinary Medicine, University of Nigeria, Nsukka, and maintained alive in mice by the serial intraperitoneal passage of blood from donor mouse to another mouse. The reinfected mice were kept at the University of Nigeria, Department of Pharmacology and Toxicology animal house unit, where the study was conducted.

\section{In vivo antimalarial studies}

Parasite inoculation: Standard inoculum consisting of about $1 \times 10^{7}$ of Plasmodium berghei (NK-65) parasitized erythrocytes per $\mathrm{ml}$ from donor mouse in $0.2 \mathrm{ml}$ normal saline was made. Each experimental mouse was inoculated intraperitoneally with $0.2 \mathrm{ml}$ of infected blood suspension containing Plasmodium berghei NK65 parasitized erythrocytes.

Activity on early malariainfection(suppressive test): The Peters' 4-day suppressive test against Plasmodium berghei (NK-65) infection in mice 
was employed to test for the suppressive activity of the crude extract.[24] On the first day (D0), twenty-five Swiss albino mice of both sex were inoculated intraperitoneally (IP) with $0.2 \mathrm{ml}$ of standard inoculum of parasitized erythrocyte as described above. The mice were divided into 5 groups of 5 mice each (i.e., 5 mice per group) and treated for 4 consecutive days (D0 - D3). Group I mice (control) were administered $10 \mathrm{ml}$ distilled water $/ \mathrm{kg}$ body weight daily. Groups 2 , 3 , and 4 were administered with 200, 400, and $800 \mathrm{mg}$ extract $/ \mathrm{kg}$ body daily, respectively. The administration was done orally using an intragastric cannula. Group 5 mice were treated with artesunate $10 \mathrm{mg} / \mathrm{kg}$ body weight daily. On the 5 th day of study (D4), blood from the tail of each mouse was smeared on a microscope slide to make a thin film. The films were stained with Giemsa stain and examined under a microscope as illustrated by Huang et al.,[25] to determine parasitaemia and percentage suppression.

Percentage suppression $=(A-B / A) \times 100$

Where; $\mathrm{A}=$ mean parasitaemia in the negative control group; $\mathrm{B}=$ mean parasitaemia in the test/standard group.

\section{Activity on established malaria infection (Rane test)}

The curative activity of $C$. nigricans crude extract against established malaria infection was evaluated following the procedure outlined by Ryley and Peters.[26] Twenty-five Swiss albino mice of both sexes were weighed and grouped into five groups of five mice each. The animals were inoculated intraperitoneally (IP) on the first day (D0) with $0.2 \mathrm{ml}$ of standard inoculum of parasitized erythrocyte and left untreated until the fourth day (D3) of study. On the fourth day (D3), blood from the tail of each mouse was smeared on a microscope slide to make a thin film. The blood films were stained with Giemsa stain and examined under a light microscope to determine pre-treatment parasitemia. The animals were treated for four days (D3 - D6). Group I mice (control) were administered with $10 \mathrm{ml}$ distilled water $/ \mathrm{kg}$ body weight per oral. Groups 2 - 4 mice were administered with 200, 400, and $800 \mathrm{mg}$ extract/kg body weight orally. At the same time, Group 5 mice were administered with artesunate $10 \mathrm{mg} / \mathrm{kg}$ body weight orally. Blood was collected from each mouse by tail bleeding on D7, and thin blood film was made on a microscope slide. The films were stained and examined under a microscope as described previously to determine posttreatment parasitemia level. The percentage parasite clearance was calculated using the following formula:

Parasite clearance $(\%)=(\mathrm{X}-\mathrm{Y} / \mathrm{X}) \times 100$

Where; $X=$ pre-treatment (D3) mean parasitaemia

$\mathrm{Y}=$ post-treatment (D7) mean parasitaemia
Mean survival time: The animals were monitored to ascertain the mean survival time (days) across each group. The mice in each group were monitored daily for mortality from the first day of infection (D0); this was continued after the treatment period till mortality of all the animals. The mean survival time was recorded for each group as described by Saidu et al.[25]

Temperature determination: The rectal temperature of each mouse in all groups was taken before infection (D0), during treatment (D3 - D6), and after treatment (D7). The temperature was taken using a digital thermometer. The change in rectal temperature of treated groups was compared with the control group.

\section{Statistical analysis}

The data obtained were expressed as the mean, standard error of the mean (Mean \pm SEM). Oneway analysis of variance (ANOVA) followed by Dunnet's post hoc test was used to test for significance. $\mathrm{P}<0.05$ was considered significant. GraphPad Prism for windows (version 7.0), San Diego California, USA was used for the analysis.

\section{RESUlTs}

\section{Phytochemical screening}

The results obtained from the phytochemical screening of $C$. nigricans crude leaf extract revealed the presence of alkaloids, cardiac glycosides, terpenoids, saponins, flavonoids, quinines, steroids, carbohydrate, taninins, proteins, and reducing sugar; while resins were absent.

\section{Acute toxicity $\left(\mathrm{LD}_{50}\right)$}

The mice appeared normal, and no mortality was recorded at all the doses used for the study after $24 \mathrm{~h}$, and throughout the two weeks observation period for delayed toxicity [Table 1]. The oral median lethal dose $\left(\mathrm{LD}_{50}\right)$ of $C$. nigricans in mice was estimated to be greater than $5000 \mathrm{mg} / \mathrm{kg}$ body weight.

Table 1. Oral acute toxicity of Combretum nigricans crude leaf extract

\begin{tabular}{|l|l|l|l|}
\hline Phase & $\begin{array}{l}\text { Extract } \\
\text { dose (mg/ } \\
\text { kg) }\end{array}$ & $\begin{array}{l}\text { No. of } \\
\text { mortality } \\
\text { after 24 } \\
\text { hours }\end{array}$ & $\begin{array}{l}\text { No. of } \\
\text { mortality } \\
\text { after 14 } \\
\text { days }\end{array}$ \\
\hline Phase 1 & 10 & $0 / 3$ & $0 / 3$ \\
\cline { 2 - 4 } & 100 & $0 / 3$ & $0 / 3$ \\
\cline { 2 - 4 } & 1000 & $0 / 3$ & $0 / 3$ \\
\hline Phase 2 & 1600 & $0 / 1$ & $0 / 1$ \\
\cline { 2 - 4 } & 2900 & $0 / 1$ & $0 / 1$ \\
\cline { 2 - 4 } & 5000 & $0 / 1$ & $0 / 1$ \\
\hline
\end{tabular}

Activity on early malaria infection (suppressive test) 
All doses of $C$. nigricans crude leaf extract gave significant $(\mathrm{P}<0.05)$ chemosuppressive effect against $P$. berghei, this effect was observed to be dose-related [Table 2]. The percent chemo suppression were $49.1,57.5$ and $75.5 \%$ for 200 , 400 and $800 \mathrm{mg} / \mathrm{kg}$ doses respectively, while artesunate gave $78.3 \%$ [Figure 1].

Table 2. Chemosuppressive activity of $C$. nigricans crude leaf extract in $\mathcal{T}$. berghei infected mice

\begin{tabular}{|l|l|l|}
\hline Treatment & Dose $(\mathrm{mg} / \mathrm{kg})$ & $\begin{array}{l}\text { Mean parasite } \\
\text { count }\end{array}$ \\
\hline Control & $10 \mathrm{ml} / \mathrm{kg}$ & $21.2 \pm 0.80$ \\
\hline \multirow{3}{*}{ C. nigricans } & 200 & $10.8 \pm 1.02^{*}$ \\
\cline { 2 - 3 } & 400 & $9.0 \pm 1.10^{*}$ \\
\cline { 2 - 3 } & 800 & $5.2 \pm 0.37^{*}$ \\
\hline Artesunate & 10 & $4.6 \pm 0.24^{*}$ \\
\hline
\end{tabular}

Values expressed as Mean \pm SEM, where $n=5$, *significant at $\mathrm{P}<0.05$

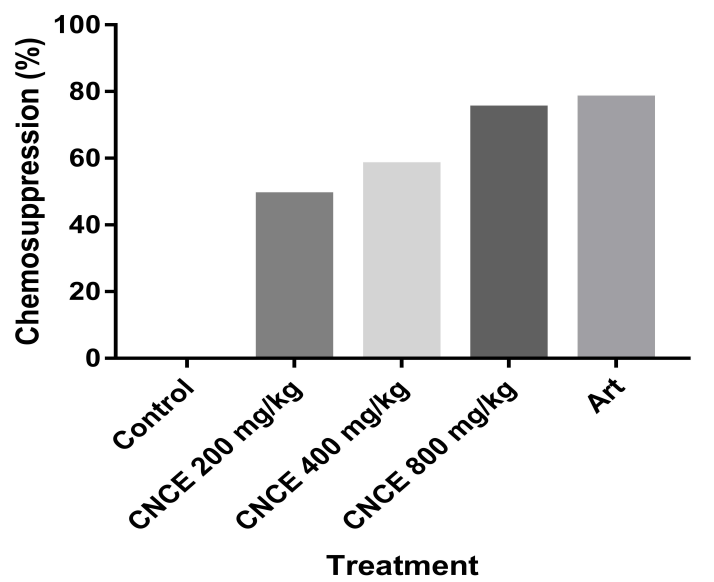

Figure 1. Percent chemosuppressive activity of $C$. nigricans crude extract against $\mathcal{T}$. berghei in mice. Art $=$ artesunate, $\mathrm{CNCE}=$ Combretum nigricans crude leaf extract.

Activity on the established infection (Rane test)

The crude extract exhibited a significant $(\mathrm{P}<0.05)$ curative effect in established infection [Table 3].
The erythrocyte parasite clearance was $41.3 \%$, $69.4 \%$, and $64.8 \%$ for 200,400 , and $800 \mathrm{mg} / \mathrm{kg}$, respectively, while artesunate gave $69.2 \%$. No parasite clearance was observed in the control group, but rather there was an increase by $28.2 \%$ [Figure 2].

Table 3. Curative activity of $\mathcal{C}$. nigricans crude leaf extract in $\boldsymbol{T}$. berghei infected mice

\begin{tabular}{|l|l|l|l|}
\hline Treatment & \multirow{2}{*}{$\begin{array}{l}\text { Dose } \\
(\mathrm{mg} / \mathrm{kg})\end{array}$} & \multicolumn{2}{|l|}{ Mean parasite count } \\
\cline { 3 - 4 } & $10 \mathrm{ml} / \mathrm{kg}$ & $28 \pm 1.3$ & $35.9 \pm 1.78$ \\
\hline Control & Day 3 & Day 7 \\
\hline \multirow{2}{*}{$\begin{array}{l}\text { C. } \\
\text { nigricans }\end{array}$} & 200 & $25.2 \pm 0.6$ & $14.8 \pm 1.9^{*}$ \\
\cline { 2 - 4 } & 400 & $26.8 \pm 1.7$ & $8.2 \pm 1.07^{*}$ \\
\cline { 2 - 4 } & 800 & $26.4 \pm 1.2$ & $9.3 \pm 0.3^{*}$ \\
\hline Artesunate & 10 & $26 \pm 3.5$ & $8 \pm 0.58^{*}$ \\
\hline
\end{tabular}

Values expressed as Mean \pm SEM, where $n=5$, *significant at $\mathrm{P}<0.05$

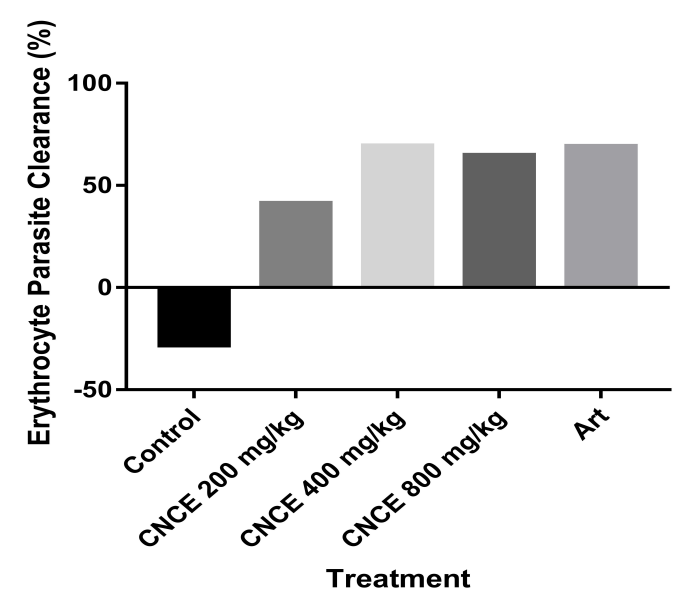

Figure 2. Erythrocyte clearance of $\mathcal{T}$. berghei by $\mathcal{C}$. nigricans crude leaf extract in mice. Art = artesunate, $\mathrm{CNCE}=$ Combretum nigricans crude leaf extract.

There was a progressive decrease in mice body temperature of the control from study D3 through D7. This observed decrease in body temperature was as low as 32.6 OC on D7. C. nigricans extract substantially prevented the decrease of temperature in a dose-related manner, with $C$.

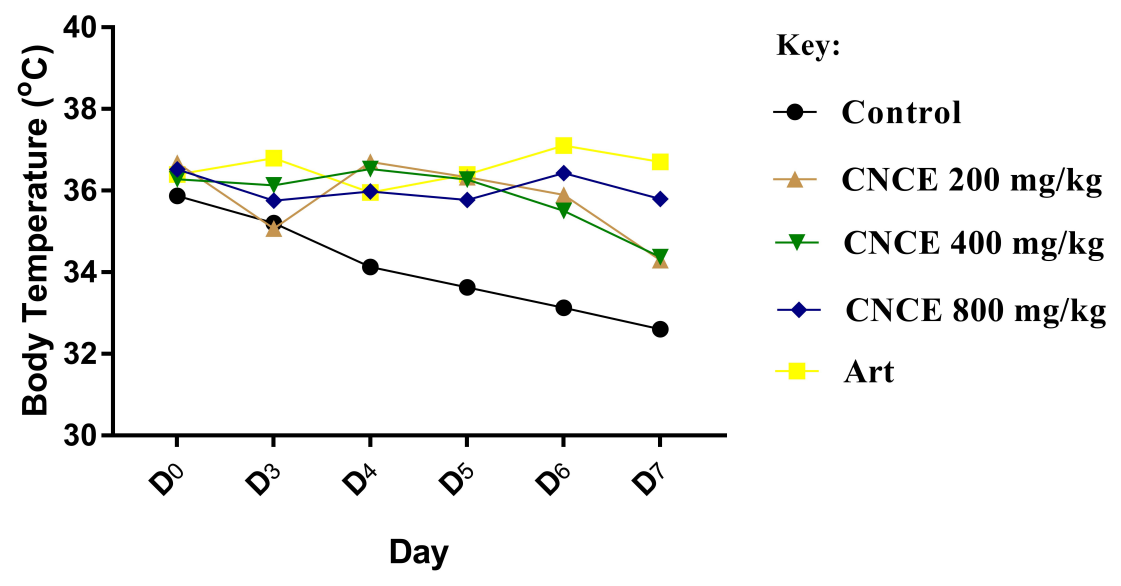

Figure 3. Effect of $C$. nigricans crude leaf extract on the body temperature of mice infected with $P$. berghei (curative test). Art = artesunate, $\mathrm{CNCE}=$ Combretum nigricans crude leaf extract. 
nigricans $800 \mathrm{mg} / \mathrm{kg}$ dose giving the highest effect. The standard drug artesunate also had the same effect of preventing body temperature decrease [Figure 3].

There was a prolongation in the mean survival time of the extract-treated groups, and the artesunate treated group compared to the control. This effect was also dose-dependent and was significant $(\mathrm{P}<0.05)$ in all the treated groups except the group treated with $200 \mathrm{mg}$ extract $/ \mathrm{kg}$, in which the effect was not significant $(\mathrm{P}<0.05)$. The mean survival time of the control group was 11.0 days, while that of the groups administered crude extract were $13.5,16.0$, and 18.5 days for 200,400 , and $800 \mathrm{mg} / \mathrm{kg}$, respectively. The group administered artesunate had the longest survival time, 21.3 days [Figure 4].

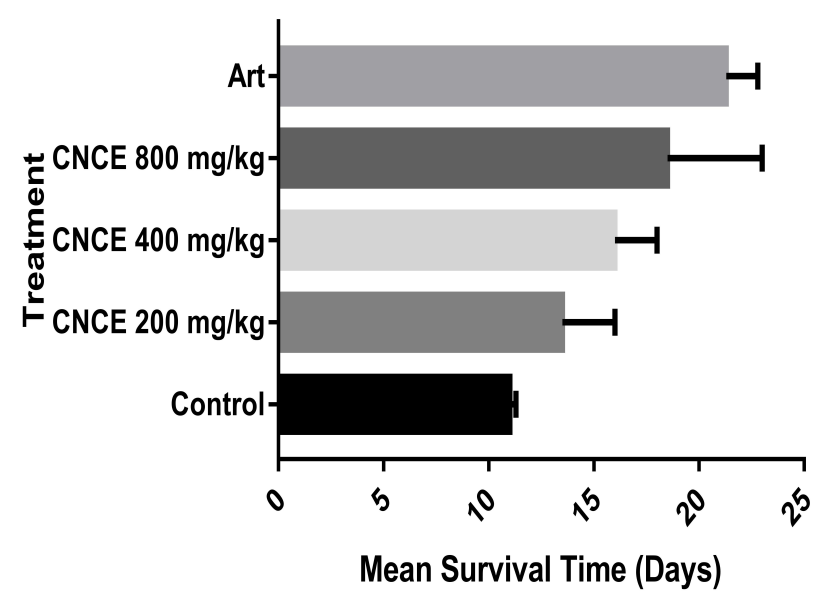

Figure 4. Effect of $C$. nigricans on the mean survival times of mice infected with $\boldsymbol{T}$. berghei in curative test. Art = artesunate, $\mathrm{CNCE}=$ Combretum nigricans crude extract.

\section{Discussion}

In this study, the in vivo antimalarial activity of Combretum nigricans, a plant used in traditional medicine in North-Central Nigeria, was evaluated on Plasmodium berghei infected mice using the suppressive and curative in vivo models. In vivo models were employed for this study because it considers possible pro-drug effect and possible involvement of immune system in the extermination of the infection.[27, 12] Rodent Malaria models (especially P. berghei) are known to elicit disease features similar to those of human Plasmodial infection,[28 30] hence are used in preclinical research to predict possible clinical outcomes of prospective antimalarial agents. The rodent malaria model identified several important antimalarial agents such as chloroquine, halofantrine, mefloquine, and artemisinin.[31] These facts, therefore, justify its application for the study.

The Peters' 4-day suppressive test on early malaria infection and Rane's curative test on established malaria infection is commonly employed for screening antimalarial agents. In both methods, the reduction of parasitemia in the treated group to a level $\leq 90 \%$ of the control (untreated) group indicates a potent antimalarial activity by the test agent.[32]

The result obtained from the study showed that all doses of the crude extract demonstrated significant $(\mathrm{P}<0.05)$ antimalarial activity in both test models. The extract gave a significant $(\mathrm{P}<0.05) \quad$ chemosuppressive effect against $P$. berghei in a dose-related fashion in the suppressive study. The highest chemosupressive activity by the extract (75.5\% chemosuppression) was observed in the group treated with $800 \mathrm{mg} /$ $\mathrm{kg}$ (highest test dose). This effect was closely related to that elicited by artesunate $(78.3 \%$ chemosuppression), the standard antimalarial drug used for the study.

The extract also demonstrated significant $\mathrm{P}<0.05)$ erythrocyte clearance of the Jasmodium parasite in the curative study. the highest extract activity was observed in he administered $400 \mathrm{mg}$ extract/kg (69.4\%); lowever, this was relatively close to the parasite :learance elicited by the highest test dose, 800 $\mathrm{ng} / \mathrm{kg}(64.8 \%)$. This may serve as an indication hat $C$. nigricans crude extract $400 \mathrm{mg} / \mathrm{kg}$ nay be the best therapeutic dose in mice. The :ontrol group showed a significant decrease in ody temperature, which progressed till D7, his decrease in body temperature was less $\mathrm{n}$ the extract-treated groups and artesunate ;roup. Though fever (pyrexia) is one of the major nanifestations of malaria in humans [33], it is lifferent in the rodent model of malaria, which s usually characterized by hypothermia rather than pyrexia.[34] Previous studies have shown that the body temperature of mice infected with P. berghei will progressively decrease significantly from the fourth day of infection if left untreated. [35, 36] This sustained hypothermia in $P$. berghei infected mice may be attributed to the general debilitating effects of malaria on the host, resulting in excessive body heat loss and ultimately leading to death.[36] The treatment of $P$. berghei infected mice with a potent antimalarial agent will prevent this phenomenon (i.e., hypothermia); this is because the body temperature of $P$. berghei infected mice usually decreases as the parasite level increases; hence agents that prevent parasite increase will also prevent the significant decrease of body temperature. Hence the effect of the extract on the body temperature of the treated mice can be attributed to its antiplasmodial activity, while the substantial decrease in the body temperature of the control group, which progressed till the eightday (D7), maybe due to a progressive increase in the erythrocyte parasite level. The extract also prolonged the mean survival time in the curative test. This effect was significant in groups treated with extract doses of 400 and $800 \mathrm{mg} /$ $\mathrm{kg}$, which had a mean survival time of 16.0 and 18.5 days, respectively. Mean survival time is a useful parameter for evaluating the antimalarial efficacy of potential antimalarial agents.[37] A candidate antimalarial agent is considered 
potent if the mice in the treatment group survive for more than 12 days after infection. These observations have demonstrated that the $C$. nigricans crude extract is a potent antimalarial agent; however, the therapeutic effects of plant extracts are known to be elicited by the bioactive chemicals (phytochemicals) present in them. Hence, the extract's antimalarial activity may also be due to the phytochemicals present in it. The phytochemical assessment results revealed the presence of several important phytochemicals in the extract whose antimalarial activities have been documented. Among them are terpenoids, alkaloids, saponins, and flavonoids.[38 - 41] Terpenoids are known to possess oxidant generating potential, which elicits antiplasmodial and cytotoxic effects. The cytotoxic effect of pentacyclic triterpenes (a class of terpenoids) isolated from $C$. nigricans has previously been reported by Simon et al.[44] Similarly, the antiplasmodial activity of triterpenes isolated from the methanolic leaf extract of Combretum racemosum (a plant from the Combretum genus also) has also been reported.[45] The mechanism of action of artemisinin (a terpenoid isolated from Atermesia annua) and its derivatives (including artesunate) against Plasmodium parasites is based on their oxidant producing activity and has also been reported to possess cytotoxic activity against invasive breast ductal carcinoma.[46] This evidence suggests that terpenoids present in $C$. nigricans are the culprit antiplasmodial principle in the plant and may elicit their antiplasmodial effect through oxidant producing mechanism. Aside from antiplasmodial activity elicited by terpenoids, other bioactive components such as flavonoids, alkaloids, and saponins present in the extract may have also elicited complementary antiplasmodial effects.[39, 40, 47] [42, 43]

The acute toxicity test result showed that the oral median lethal dose of $C$. nigricans crude extract was more remarkable than $5000 \mathrm{mg} / \mathrm{kg}$ in mice. According to previous studies, therapeutic agents with oral acute toxicity values greater than 5000 $\mathrm{mg} / \mathrm{kg}$ are considered safe or practically nontoxic. [48, 49] This therefore, indicates that the extract also has a wide therapeutic window in mice coupled with its antimalarial potency.

\section{Conclusion}

The result from the study indicates that $C$. nigicans crude leaf extract possesses significant antimalarial activity, which may serve as a scientific justification for its application as an antimalarial agent ethnomedicine.

Conflict of interest: None.

Funding: This research did not receive any specific grant from funding agencies in public, commercial, or not-for-profit sectors.

\section{REFERENCES}

1. Hay SI, Okiro EA, Gething PW, Patil A, Tatem
AJ. Estimating the global clinical burden of Plasmodium falciparum Malaria in 2007. PLoS Med 2010;7:e1000290

2. World Health Organization. World malaria report 2013. Available online at: http://www. who.int/malaria/publications/world_malaria_ report_2013/report/en/

3. Murray CJ, Rosenfeld LC, Lim SS. Global malaria mortality between 1980 and 2010: a systematic analysis. Lancet 2012;379:413-31

4. Fairhusrt RM, Wellems TE. Malaria (Plasmodium species). In: Bennett JE, Dolin $\mathrm{R}$, Blaser MJ. editors. Mandell, Douglas, and Bennett's Principles and Practice of Infectious Diseases 8th Ed. Elsevier Saunders; Philadelphia, PA:2015.

5. Liu Y, Zhou R, Zhang Y, Wang D, Li S, Yang $\mathrm{C}$, et al. analysis of polymorphisms in the circumsporozoite protein gene of Plasmodium vivax isolates from Henan Province. China. Malaria J 2018;17:10-13

6. World Health Organization Fact sheet 2015. World malaria report Available online at: http: / / www.who.int/malaria/media/worldmalaria-report-2015/en/

7. Vinetz MJ. Chemotherapy of malaria. In: Brunton LL, Hilal-Dandan R, Knollmann CB editors. Goodman and Gilman's The Pharmacological Basis of Therapeutics 13th Ed., New York, USA; McGraw-Hill:2018.

8. White NJ, Pukrittayakamee S, Hien TT, Faiz MA, Mokuolu OA, Dondorp AM. Malaria. Lancet, 2014;383:723-35

9. Garcia-Bustos JF, Gamo FJ. Antimalarial drug resistance and early drug discovery. Curr Pharm Des, 2013;19:270-81

10. Artimovich E, Schneider K, Taylor TE, Kublin JG, Dzinjalamala FK, Escalante AA, Plowe CV et al. Persistence of sulfadoxine-pyrimethamine resistance despite reduction of drug pressure in Malawi. J Infect Dis, 2015, 212:694-701

11. Chinedu E, David A, Ameh SF. Phytochemical evaluation of the ethanolic extracts of some Nigerian herbal plants. Drug Dev Ther 2015;6:11-4

12. Mekonnen LB. In vivo antimalarial activity of the crude root and fruit extracts of Croton macrostachyus (Euphorbiaceae) against Plasmodium berghei in mice. $\mathrm{J}$ Tradit Complement Med 2015;5(3):168-73

13. Asase A, Oteng-Yeboah AA, Odamtten GT, Simmonds MS. Ethnobotanical study of some Ghanian antimalarial plants. J Ethnopharmacol, 2005;99(2):273-79

14. Alli LA, Adesokan AA, Salawu OA, Akanji M, Tijani AY. Antiplasmodial activity of aqueous 
root extract of Acacia nilotica. Afr $\mathrm{J}$ Biochem Res 2011;5:214- 19

15. Chinedu E, Arome D, Solomon FA. Herbal plants a reliable source for drug discovery and development. Pharmatutor Art, 2017. Available online at: http://www.pharmatutor.org/ articles / herbal-plants-reliable-source-drugdiscovery-development.

16. Baba-Moussa F, Akpagana K, Bouchet $\mathrm{P}$. Antifungal activities of seven West African Combretaceae used in traditional medicine. $\mathrm{J}$ Ethnopharmacol 1999;66:335-8

17. Waterman C, Smith RA, Pontiggia L, DerMarderosian A. Anthelmintic screening of Sub-Saharan African plants used in traditional medicine. J Ethnopharmacol 2010;127:755-9

18. Simon G, Dewelle J, Nacoulma O, Guissou P, Kiss R, Daloze D et al. Cytotoxic pentacyclic triterpenes from Combretum nigricans. Fitoterapia 2003;74:339-44

19. 19. Handa SS, Khanuja SPS, Longo G, Rakesh DD. Extraction Technologies for Medicinal and Aromatic Plants. International Centre for Science and High Technology ICS-UNIDO, Trieste, Italy; 2008.

20. 20. Harborne JB. "Phytochemical Methods: A Guide to Modern Techniques of Plant Analysis." 2nd Ed., London, Chapmann and Hall Publishers; 1998.

21. Evans WC. Trease and Evans Pharmacognosy, (14th ed), London, WB Saunders Company Limited;2005:357-8

22. NIH. Guide for the care and use of Laboratory animal (Revised). Washington: NIH Publication; 1985 , p. $83-23$

23. Lorke D. A new approach for acute toxicity testing. Arch Toxicol 1983;54:275-89

24. Peters W, Portus JH, Robinson BL. "The chemotherapy of rodent malaria. XXII. The value of drug-resistant strains of P.berghei in screening for blood schizonticidal activity". Ann Trop Med Parasitol 1975;69:155-71

25. Huang BW, Pearman E, Kim CC. Mouse Models of Uncomplicated and Fatal Malaria. Bio-protocol 2015;5(13):e1514

26. Ryley JF, Peters W. The antimalarial activity of some quinoline esters. Ann Trop Med Parasitol 1970;64:209-22

27. Waako PJ, Gumede B, Smith P, Folb PI. The in vitro and in vivo antimalarial activity of Cardiospermum halicacabum L. and Momordica foelida Schumch. Et Thonn. J Ethnopharmacol 2005;99:137-43

28. Pierrot C, Adam E, Lafitte S, Godin C, Dive D, Capron M, Khalife J. Agerelated susceptibility and resistance to Plasmodium berghei in mice and rats. Exp Parasitol 2003;104:81-85

29. Pedroni HC, Bettoni CC, Spalding SM, Costa TD. Plasmodium berghei: Development of an irreversible experimental malaria model in wistar rats. Exp. Parasitol 2006;113:193-96

30. Thomas AM, Van Der Wel AM, Thomas AW, Janse CJ, Waters AP. Transfection system for animal models of malaria. Parasitol Today $1998 ; 14: 248-9$

31. Khan ME, Amupitan JO, Oyewale AO, Ndukwe IG. Evaluation of the in vivo anti malarial activity of the methanolic leaf extract of Nepata cateria. Res Pharmaceut Biotech 2015;6(2):815

32. Okokon JE, Ofodum KC, Ajibesin KK, Danladi $\mathrm{B}$, Gamanil KS. Pharmacological screening and evaluation of antiplasmodial activity of Croton Zambesicus against Plasmodium berghei in mice. Indian J Pharmacol 2005;379:243-6

33. Perera MK, Herath NP, Pathirana SL, PhoneKyaw M, Alles HK, Mendis KN, et al. Association of high plasma TNF-alpha levels and TNFalpha/IL-10 ratios with TNF2 allele in severe P. falciparum malaria patients in Sri Lanka. Pathog Glob Health. 2013;107:21-9

34. Ojurongbe O, Ojo JA, Adefokun DI, Abiodun OO, Odewale G, Awe EO. In vivo Antimalarial Activities of Russelia Equisetiformis in Plasmodium Berghei. Infected Mice Indian J Pharm Sci. 2015;77(4):504-10

35. Hassen BD, Pappas PW. Acute malaria: Effects of Plasmodium berghei on the metabolic rate of mice. Ohio J Sci 1977;77(4):189.

36. Basir R, Fazalul RSS, Hasballah K, Chong WC, Talib H, Yam MF et al. Plasmodium berghei ANKA Infection in ICR Mice as a Model of Cerebral Malaria. Iranian J Parasitol 2012;7:62-74

37. Adugna M, Feyera T, Taddese W, Admasu P. In Vivo Antimalarial Activity of Crude Extract of Aerial Part of Artemisia abyssinica against Plasmodium berghei in Mice. Global J Pharmacol 2014;8:460-8

38. Philipson JD, Wright CW Can ethnopharmacology contribute to the development of antimalarial agents. J Ethnopharmacol 1990;32:115-65

39. Chierrito TPC, Aguiar ACC, de Andrade IM, Ceravolo IP, Gonçalve RAC et al. Anti-malarial activity of indole alkaloids isolated from Aspidosperma olivaceum. Malaria Journal 2014;13:142

40. Christensen SB, Kharazmi A. Antimalarial natural products: isolation, characterization and biological properties. In Bioactive compounds from natural sources: Isolation, 
Characterization and biological properties, Tringali C (ed). Taylor and Francis: London:2001.

41. Go ML. Novel antiplasmodial agents. Medicinal Plant Rev 2003;23: 456-87

42. Lui KC, Yang SC, Roberts MF. Antimalarial activity of Artemisia annua flavonoids from whole plants and cell cultures. Plants Cell 1992;II:637-40

43. Okonkon JE, Antia BS, Azare BA, Okokon PJ. Antiplasmodial activity and cytotoxicity of ethanol extract of Zea mays root. Avicenna J Phytomed, 2017;7(3): 275-84

44. Simon G, Dewelle J, Nacoulma O, Guissou P, Kiss R, Daloze D et al. Cytotoxic pentacyclic triterpenes from Combretum nigricans. Fitoterapia 2003;74:339-44

45. Oluyemi WM, Samuel BB, Kaehlig H, Zehl M,Parapini S, D'Alessandro S, Taramelli D, Krenn L. Antiplasmodial activity of triterpenes isolated from the methanolic leaf extract of Combretum racemosum P. Beauv. J Ethnopharmacol 2020;247:112203

46. Weathers PJ, Elkholy S, Wobbe KK. Artemisinin: The Biosynthetic Pathway and Its Regulation in Artemisia annua, a Terpenoid-Rich Species. In Vitro Cellular \& Developmental Biology. Plant 2006;42(4):309-17

47. Kabiru YA, Okolie NL, Muhammad HL, Ogbadoyi EO. Preliminary studies on the antiplasmodial potential of aqueous and methanol extracts of eucalyptus camadulensis leaf. Asian Pacific J Tropical Dis 2012;2:S809-S14

48. Syahmi ARM, Vijayarathna S, Sasidharan S, Latha YL, Kwan YP, Lau YL et al. Acute oral toxicity and brine shrimp lethality of Elaeis guineensis Jacq., (Oil Palm leaf) methanol extract. Molecules 2010;15:8111-21

49. Kennedy GL, Ferenz RLJ, Burgess BA. Estimation of acute toxicity in rats by determination of the appromate lethal dose rather than LD50. J Appl Toxicol 1986;6:145-8 